\title{
Keragaan Penampilan Mutan Jagung Manis (Zea mays saccharata) Generasi M3 Berdasarkan Karakter Fenologi Di Karawang
}

\author{
(Appearance performance of M3 Generation of Sweet Corn (Zea mays saccharata) Mutans Based on \\ Phenological Characters in Karawang)
}

\author{
Mufti Alma Adiwijaya ${ }^{1}$, Rika Yayu Agustini $^{2}$, Muhammad Syafi' ${ }^{2 *}$ \\ ${ }^{1,2}$ Program Studi Agroteknologi, Fakultas Pertanian, Universitas Singaperbangsa Karawang \\ *Penulis Koresponding : muhammad.syafii@staff.unsika.ac.id
}

\begin{abstract}
Abstrak
Pengembangan jagung di Indonesia yang intensif mengakibatkan munculnya berbagai masalah baik penurunan produktivitas maupun kualitas hasil. Salah satu cara yang dilakukan untuk mendapatkan hasil benih tanaman jagung berkualitas dan varietas unggul yaitu dengan penyeleksian budidaya beberapa galur hasil iradiasi sinar gamma yang merupakan mutagen paling banyak digunakan dalam memproduksi varietas mutan. Penelitian ini bertujuan untuk mendapatkan mutan jagung manis yang paling baik sehingga dapat meningkatkan pertumbuhan karakter fenologi. Penelitian ini dilaksanakan mulai bulan agustus sampai oktober 2020 di kebun percobaan Balai Besar Peramalan Organisme Pengganggu Tanaman (BBPOPT) . Metode penelitian menggunakan rancangan acak kelompok (RAK) dengan faktor tunggal di ulang 9 kali. Perlakuan menggunakan 10 galur mutan jagung manis. Perlakuan mutan jagung manis adalah G1M1 (Galur 1 mutan 100 gy), G2M1 (Galur 2 mutan 100 gy), G3M2 (Galur 3 mutan 200 gy), G4M1 (Galur 4 mutan 100 gy), G5M3 (Galur 5 mutan 300 gy), G6M1 (Galur 6 mutan 100 gy), G7M3 (Galur 7 mutan 300 gy), G8M2 (Galur 8 mutan 200 gy), G9M1 (Galur 9 mutan 100 gy) dan G10M0 (Galur 10 mutan 0 gy). Terdapat perlakuan terbaik antara galur jagung manis dan dosis iradiasi sinar gamma, pengaruh terbaik terdapat pada perlakuan G3M2 pada parameter pengamatan umur bunga betina $(53,78 \mathrm{hst})$, anthesis silking interval $(2,64$ hari), umur panen (76,0 hst) dan G9M1 pada parameter pengamatan lama produksi polen (4,82 hari), lama pengisian buah (13,73 hari).
\end{abstract}

Kata Kunci : Galur, Iradiasi, Jagung Manis, Fenologi

\section{PENDAHULUAN}

Jagung juga merupakan sumber bahan baku bagi sektor industri termasuk industri pangan (Listyaningsih et., al, 2018). Menurut Suprapto (2012) Pengembangan jagung di Indonesia yang intensif mengakibatkan munculnya berbagai masalah baik penurunan produktivitas maupun kualitas hasil. Penurunan produktivitas maupun kualitas hasil jagung sangat ditentukan oleh faktor abiotik dan biotik. Kendala dalam budidaya jagung menyebabkan rendahnya produktivitas jagung antara lain serangan hama dan penyakit sebagai faktor biotik. Produksi jagung pada tahun 2014-2018 meningkat $58,05 \%$, dari 19 juta ton pada tahun 2014 menjadi 30 juta ton pada tahun 2018 (ARAM I, BPS 2018). Luas panen meningkat sebesar $49,54 \%$ dan produktivitas meningkat 5,69\%. Menurut Rifianto (2010) tanaman jagung manis umumnya ditanam untuk dipanen muda yaitu $69-82$ hari setelah tanam atau pada saat masak susu (milking stage).

Galur merupakan keturunan hasil persilangan (selfing) yang mempunyai karakter agronomis tertentu dan biasanya belum mencapai kemantapan dan belum diberi nama, sehingga diperlukan uji galur sebelum akhirnya dilepas di pasaran (Wigathendi et al, 2014). Karakterisasi merupakan upaya mendeskripsikan karakter dari tanaman dan menghasilkan informasi mengenai karakter dari tanaman untuk dijadikan calon varietas.

Salah satu cara yang dilakukan untuk mendapatkan hasil benih tanaman jagung berkualitas dan varietas unggul yaitu dengan penyeleksian budidaya beberapa galur hasil iradiasi gamma. Sinar gamma merupakan mutagen yang paling banyak digunakan dalam memproduksi varietas mutan (Soeranto, 2003). Sinar gamma diperoleh dari peluruhan zat radioaktif yang dipancarkan dari atom dengan kecepatan tinggi karena kelebihan energi.

Menurut Fewless (2006), Fenologi merupakan karakter penting dalam adaptasi suatu tanaman terhadap perubahan lingkungan tumbuh yang dapat terjadi secara alami atau dikondisikan pada lingkungan tertentu. Fenologi terkait dengan terjadinya perubahan fase-fase pertumbuhan, perkembangan, pembungaan hingga pematangan buah. Fenologi perbungaan suatu jenis tumbuhan adalah salah satu karakter penting dalam siklus hidup tumbuhan karena pada fase itu terjadi proses awal bagi suatu tumbuhan untuk berkembang biak. Suatu tumbuhan akan memiliki perilaku yang berbeda-beda pada pola perbungaan dan perbuahannya, akan tetapi pada umumnya diawali dengan pemunculan bunga dan akhiri dengan pematangan buah (Tabla dan Vargas, 2004).

Tujuan dari penelitian ini adalah untuk mendapatkan mutan jagung manis (Zea mays saccharata) generasi M3 yang paling baik berdasarkan karakter fenologi. 


\section{BAHAN DAN METODE}

\section{Tempat dan Waktu}

Penelitian ini dilaksanakan di Kebun Percobaan Balai Besar Peramalan Organisme Pengganggu Tanaman yang berlokasi di Jalan Raya Pantura Pangulah Utara, Kecamatan Kota Baru, Kabupaten Karawang, Provinsi Jawa Barat, dilakukan selama 3 bulan yaitu pada bulan Agustus sampai Oktober 2020.

\section{Bahan dan Alat}

Bahan yang digunakan dalam penelitian ini adalah benih galur manis sebanyak 10 galur yang telah diinduksi sinar gamma 60-co dengan dosis (0 Gy, 100 Gy, 200 Gy dan 300 $\mathrm{Gy}$ ), pupuk urea, pupuk phonska dan $\mathrm{KCl}$.

Alat yang digunakan dalam penelitian ini adalah cangkul, tugal, ajir, meteran, jaring, batang bambu, papan seng, label, kertas amplop samson, timbangan analitik, alat tulis kantor, thermohygrometer, kamera hp, dan lain-lain.

\section{Metode Penelitian}

Metode penelitian yang digunakan adalah metode eksperimen dengan menggunakan Rancangan Acak Kelompok (RAK) faktor tunggal sebanyak 10 perlakuan dan diulang 9 kali.

Tabel 1. Perlakuan galur jagung manis

\begin{tabular}{cccc}
\hline No & Perlakuan & No & Perlakuan \\
\hline 1 & G1M1 & 6 & G6M1 \\
2 & G2M1 & 7 & G7M3 \\
3 & G3M2 & 8 & G8M2 \\
4 & G4M1 & 9 & G9M1 \\
5 & G5M3 & 10 & G10M0 \\
\hline
\end{tabular}

Analisis ragam (Analysis of Variance) dilakukan untuk semua data hasil pengamatan utama. Dilakukan jika hasil uji $\mathrm{F}$ untuk perlakuan dalam analisis ragam menunjukkan berbeda nyata ( $\mathrm{F}$ hit $>\mathrm{F}$ tabel 5\%), maka untuk mengetahui perlakuan yang paling baik dilanjutkan pengujian beda rata-rata perlakuan dengan menggunakan Duncan Multiple Range Test (DMRT) pada taraf 5\% (Gomez dan Gomez, 2010).

Variabel pengamatan pada penelitian ini adalah umur bunga jantan $50 \%$, umur bunga betina $50 \%$, anthesis silking interval, lama produksi polen, lama produksi buah dan umur panen $50 \%$.

\section{HASIL DAN PEMBAHASAN}

Hasil analisis ragam rata-rata bahwa parameter umur bunga jantan menunjukkan galur G6M1 dengan hasil 44,56 yang memiliki umur keluar bunga jantan tercepat diantara galur-galur lainnya, yang terlambat terdapat pada galur G1M1 dengan hasil 42,78. Sedangkan Kemunculan umur bunga betina pada galur G3M2 dengan hasil 53,78 yang memiliki umur keluar betina tercepat diantara galurgalur lainnya, yang terlambat terdapat pada galur G1M1 dengan hasil 51,44. Sejalan dengan pendapat Harjadi (2002) bahwa umur berbunga tanaman tergantung pada galur dan genetik serta adanya faktor lingkungan, serta maisng-masing galur mempunyai ciri khas tersendiri. Hal ini disebabkan faktor suhu lebih tinggi dari pada suhu rata-rata. Rata-rata umur keluar bunga jantan yaitu 41-50 hari dan rata-rata umur keluar bunga betina yaitu 48-56 hari. Sejalan dengan pendapat Lakitan (2012), bahwa pembungaan suatu tanaman dipengaruhi oleh faktor genetik dan sifat tanaman itu sendiri.

Tabel 2. Rekapitulasi analisis sidik ragam pada keragaan parameter komponen fenologi hasil galur-galur jagung manis pada generasi M3

\begin{tabular}{lllllll}
\hline \multirow{2}{*}{ Sumber Keragaman } & \multicolumn{5}{c}{ Parameter Pengamatan } \\
\cline { 2 - 7 } & UBJ & UBB & ASI & LPP & LPB & UP \\
\hline Ulangan & 11,42 & 6,7 & 0,29 & 0,69 & 0,58 & 1,27 \\
Galur & 2,45 & 3,93 & 0,45 & 0,33 & 0,17 & 0,55 \\
Galat & 5,74 & 3,76 & 0,2 & 0,28 & 0,27 & 0,76 \\
F hitung U & $1,99 \mathrm{~ns}$ & $1,78 \mathrm{~ns}$ & $1,45 \mathrm{~ns}$ & $2,52^{*}$ & $2,15 *$ & $1,69 \mathrm{~ns}$ \\
F hitung G & $0,43 \mathrm{~ns}$ & $1,05 \mathrm{~ns}$ & $2,25 *$ & $1,20 \mathrm{~ns}$ & $0,62 \mathrm{~ns}$ & $0,72 \mathrm{~ns}$ \\
F tabel U & 2,07 & 2,07 & 2,07 & 2,07 & 2,07 & 2,07 \\
F tabel G & 2,01 & 2,01 & 2,01 & 2,01 & 2,01 & 2,01 \\
KK $(\%)$ & $5,49 \%$ & $3,69 \%$ & $19,24 \%$ & $11,48 \%$ & $3,48 \%$ & $1,15 \%$ \\
\end{tabular}

Selain faktor genetik, faktor yang mempengaruhi kemunculan umur bunga jantan dan betina pada galur jagung ini adalah umur muncul bunga jantan dan bunga betina yang berkaitan dengan pertumbuhan tinggi tanaman dan jumlah daun. Tingginya tanaman disebabkan pertambahan ruas batang tempat keluarnya daun sehingga mempengaruhi jumlah daun yang dihasilkan. Peningkatan jumlah daun menyebabkan jumlah cahaya yang dapat ditangkap tanaman akan meningkat pula, semakin besar cahaya yang ditangkap maka fotosintesis akan berlangsung cepat, jika fotosintesis cepat maka hasil asimilat yang diperoleh tanaman makin banyak akan berpengaruh terhadap laju pertumbuhan vegetatif tanaman. Laju pertumbuhan vegetatif baik, tanaman akan segera memasuki fase generatif yang diawali dengan pembentukan bunga jantan. Oleh sebab itu, terbatasnya tinggi tanaman dan jumlah daun pada tanaman kontrol mengakibatkan umur muncul bunga jantan dan betina 
lebih lama di bandingkan dengan dengan galur-galur tanaman jagung.

Rata-rata perbedaan waktu terlepasnya serbuk sari (anthesis) dengan waktu keluarnya rambut tongkol (silking) pada jagung manis genotipe G5M3 yaitu sekitar 2,40 hari dan tidak signifikan terhadap galur lainnya. Selisih waktu yang paling cepat yaitu 1,91 hari pada galur G8M2, sedangkan yang terlama terjadi pada galur G3M2 yang mencapai hingga 2,64 hari. Walaupun demikian, kemunculan rambut tongkol tersebut masih dalam rentang waktu pollen sedang diproduksi oleh malai pada tanaman yang sama. Sehingga rambut tongkol jagung manis galur G5M3 dan galur lainnya masih siap dan dapat diserbuki pada masa produktif dihasilkannya pollen. Basry (2003) melaporkan bahwa selisih umur berbunga pada tanaman jagung manis dipengaruhi oleh sifat genetiknya. Adanya cekaman lingkungan akan memperpanjang selisih umur berbunga.

Hasilpengamatan lama produksi polen memberikan pengaruh nyata. Selisih waktu yang paling cepat yaitu 4,13 hari pada galur G4M1, sedangkan yang terlama terjadi pada galur G9M1 yang mencapai hingga 4,82 hari. Berdasarkan pengamatan di lapangan, serbuk sari (pollen) dapat dihasilkan oleh setiap individu tanaman selama lima hari dan tidak lebih dari enam hari sejak awal pertama terlepasnya pollen pada setiap malai. Hal ini sejalan dengan Siregar (2014), semua genotipe dan varietas jagung manis yang dievaluasi mempunyai masa efektif produksi pollen yang hampir sama untuk dapat menyerbuki rambut tongkol, dengan batas waktu produktif antara $5-6$ hari. Kebanyakan tanaman jagung manis menghasilkan pollen sebelum rambut tongkol keluar (silking). Beberapa tanaman ada yang terlambat anthesis dan didahului oleh munculnya rambut tongkol.

Hasil pengamatan lama pegisisna buah menunjukkan bahwa waktu yang paling cepat yaitu 13,31 hari pada galur G4M1, sedangkan yang terlama terjadi pada galur G9M1 yang mencapai hingga 13,73 hari. Menurut Taufik et., al, (2010) ketersediaan unsur hara tidak terlepas dari proses pengisian biji. Unsur hara yang diserap akan diakumulasikan ke dalam protein yang membentuk biji. Akumulasi bahan hasil metabolisme pada pembentukan biji akan meningkat, sehingga biji yang terbentuk memiliki ukuran dan berat yang maksimal, hal ini terjadi apabila terpenuhinya unsur hara yang menyebabkan metabolisme berjalan secara optimal.

Hasil pengamatan umur panen menunjukkan bahwa waktu yang paling cepat yaitu 75,11 pada galur G1M1, sedangkan yang terlama terjadi pada galur G3M2 yang mencapai hingga 76,00. Salunke dan Desai (1984) berpendapat bahwa umur panen pada fase masak susu (milk) ditandai dengan kadar gula yang tinggi sedangkan kadar pati rendah. Menurut Surtinah (2008) pada umur panen 80 hari kandungan gula biji jagung manis turun sampai $13.46 \%$, hal ini disebabkan karena pada saat ini terjadi perubahan gula menjadi tepung, sehingga mengu-rangi rasa manis dari biji jagung tersebut. Dan pada umur panen 80 hari serat biji jagung manis lebih kasar dibandingkan dengan umur panen yang lain.

\section{KESIMPULAN}

Hasil penelitian tersebut dapat diambil beberapa kesimpulan sebagai berikut:

1. Galur jagung manis yang telah diberikan berbagai dosis iradiasi sinar gamma (0 gy, 100 gy, 200 gy dan 300 gy) memberikan pengaruh nyata terhadap komponen fenologi tanaman jagung manis diantaranya, anthesis silking interval, lama produksi polen dan lama pengisian buah.

2. Secara keseluruhan perlakuan galur mutan jagung manis yang menunjukkan respon paling baik pada pertanaman jagung manis yaitu perlakuan G9M1 yakni dengan dosis iradiasi sinar gamma 100 gy.

\section{UCAPAN TERIMAKASIH}

Penulis mengucapkan terimakasih yang sebesarbesarnya kepada BBPOPT Jatisari Karawang yang telah memberikan fasilitas penelitian dan LPPM Universitas Singaperbangsa Karawang atas dukungan dana melalui HIBAH PRIORITAS UNSIKA (HIPKA) Skema Hibah Strategis an. Dr. Muhammad Syafi'i, SP., MP.

\section{DAFTAR PUSTAKA}

ARAM I. 2018. Hasil Rakor Kementan dan BPS, tanggal 25-27 Juli di Solo. Petunjuk Teknis Pelaksanaan Kegiatan Jagung Tahun 2018 Direktorat Jenderal Tanaman Pangan Kementrian Pertanian.

Basry Z. 2003. Uji Daya Gabung Khusus Galur-Galur Jagung Manis (Zea mays saccharata Sturt) [SKRIPSI]. Bogor (ID): Institut Pertanian Bogor.

Fewless G. 2006. Phenology.

http://www.uwgb.edu/biodiversity/phenology/index.html. (Diakses 19 Juni 2020).

Gomez, K. A dan A. A. Gomez. 2010. Prosedur Statistik untuk Penelitian Pertanian. Terjemahan Endang Sjamsudin dan Justika S. Baharsjah. Edisi ke-2. Universitas Indonesia : Jakarta.

Harjadi, S. S. 2002. Pengantar Agronomi. Gapustaka Utama. Jakarta. Hal 197.

Lakitan, B. 2012. Dasar-Dasar Fisisologi Tumbuhan. Raja Grafindo Persada. Jakarta. 203 hal.

Listyaningsih K. D. , Astuti H. P., and Wijayanti I. B., "Pengaruh Konsumsi Susu Jagung dan Senam Lansia Terhadap Tekanan Darah dan Kadar Kolesterol pada Lansia," Jurnal KesMaDaSka, vol. 9, no. 1, pp. 115-119, 2018.

Salunke, D. K. and B. B. desai, 1984. Sweet Corn. In Possharvest Bio Technology of vegetables. P. 107-116.

Siregar, Arkanuddin. 2014. Daya Hasil dan Kualitas Jagung Manis (Zea mays var saccharata Sturt.) Genotipe SD-3 dengan Empat Varietas Pembanding di Kabupaten Bogor. Skripsi. Fakultas Pertanian Institut Pertanian Bogor. Bogor.

Suprapto., Zulaiha S., dan Apriyanto, D. 2012. Infestasi Beberapa Hama Penting Terhadap Jagung Hibrida Pengembangan Dari Jagung Local Bengkulu Pada Kondisi Input Rendah di Dataran Tinggi Andisol. Penelitian Pengelolaan Sumberdaya Alam dan Lingkungan, 1 (1): 15-28.

Surtinah. 2008. Waktu panen yang tepat menentukan kandungan gula biji jagung manis (Zea mays saccharata). Jurnal Ilmiah Pertanian. 2(2):10-19.

Soeranto H. 2003. Peran Iptek Nuklir dalam Pemuliaan Tanaman untuk Mendukung Industri Pertanian, Prosiding Pertemuan dan Presentasi Ilmiah Penelitian Dasar Ilmu Pengetahuan dan Teknologi Nuklir, P3TM BATAN, Yogyakarta 8 Juli 2003, ISSN 0216-3128. 
Tabla, V.P. dan C.F. Vargas. 2004. Phenology and Phenotypic Natural Selection on the Flowering Time of a Deceit-Pollinted Tropical Orchid, Myrmecophila Christinae. Annals of Botany, 94(2): 243250.

Taufik, M., A.F. Aziez, dan Tyas, S. 2010. Pengaruh Dosis dan Cara Penempatan Pupuk NPK terhadap Pertumbuhan dan Hasil Jagung Hibrida (Zea mays. L). Agrineca 10(2) : 105-120.

Wigathendi et., al. 2014. Karakterisasi Tujuh Genotip Jagung Manis (Zea mays saccharata Sturt) Hibrida. Jurnal Produksi Tanaman, Volume 2, Nomor 8, Desember 2014, hlm.65. 